\title{
CLINICAL EVALUATION OF OROPHARYNGEAL DYSPHAGIA IN MACHADO-JOSEPH DISEASE
}

\author{
Sabrina Mello Alves CORRÊA ${ }^{1}$, Valter Nilton FELIX', \\ Jonas Lírio GURGEL ${ }^{2}$, Rubens A. A. SALLUM ${ }^{1}$ and Ivan CECCONELLO ${ }^{1}$
}

\begin{abstract}
Context - In Machado-Joseph disease, poor posture, dystonia and peripheral neuropathy are extremely predisposing to oropharyngeal dysphagia, which is more commonly associated with muscular dystrophy. Objective - To evaluate the clinical characteristics of oropharyngeal dysphagia in Machado-Joseph disease patients. Method - Forty individuals participated in this study, including 20 with no clinical complaints and 20 dysphagic patients with Machado-Joseph disease of clinical type 1, who were all similar in terms of gender distribution, average age, and cognitive function. The medical history of each patient was reviewed and each subject underwent a clinical evaluation of deglutition. At the end, the profile of dysphagia in patients with Machado-Joseph disease was classified according to the Severity Scale of Dysphagia, as described by O'Neil and collaborators. Results - Comparison between dysphagic patients and controls did not reveal many significant differences with respect to the clinical evaluation of the oral phase of deglutition, since afflicted patients only demonstrated deficits related to the protrusion, retraction and tonus of the tongue. However, several significant differences were observed with respect to the pharyngeal phase. Dysphagic patients presented pharyngeal stasis during deglutition of liquids and solids, accompanied by coughing and/or choking as well as penetration and/or aspiration; these signs were absent in the controls. Conclusions - Oropharyngeal dysphagia is part of the Machado-Joseph disease since the first neurological manifestations. There is greater involvement of the pharyngeal phase, in relation to oral phase of the deglutition. The dysphagia of these patients is classified between mild and moderate.
\end{abstract}

HEADINGS - Machado-Joseph disease. Deglutition disorders.

\section{INTRODUCTION}

Machado-Joseph disease (MJD) is a very common cerebellar ataxia and was initially described by Nakano et al. ${ }^{(13)}$ in a descended from Guilherme Machado, that emigrated from the Azores to Massachusetts, in the United States of North America (USA), afterwards moving on to other countries ${ }^{(16,26)}$.

Nowadays many families without Portuguese descent are recorded as suffering from the disease. Japan has become one of the main center of the disease, which is also found in Brazil, India, China, Australia, Spain and France ${ }^{(12)}$.

MJD patients often display progressive cerebellar ataxia, external ophthalmoplegia (for eyelid retraction), pyramidal syndrome of spasticity (exaggerated reflexes), and extra pyramidal signals (postures and movements with an abnormal twist), dysarthria, distal muscle atrophy and small fasciculations of the face and tongue ${ }^{(13)}$.

The first signs of the disease are shown in the 25 to 55 year age group, with an average of 40 years. In 1993, Takiyama et al. ${ }^{(20)}$ located the MJD gene in the chromosome 14q (the MJD chromosome) and, in 1994, Kawagushi et al. ${ }^{(9)}$ identified the defective gene as an expansion of the sequence of the trinucleotide CAG repeat.

With application of molecular genetic technology, it is possible to establish the diagnosis of MJD with great sensitivity and precision ${ }^{(11)}$. Genomic DNA can be isolated from peripheral lymphocytes by conventional methods and the fragment containing the CAG repeat sequence of the MJD gene can be treated by polymerase chain reaction, using reaction agents DMJ52 and DMJ25. The reactive products in the polymerase chain are defined using gelatinous polyacrylamide plates $6 \%$, in parallel with markers of known molecular weight. The sum of the differences of the various pairings is equal to $\mathrm{T}$, the allele size, and the equation $\mathrm{N}=[(\mathrm{T}-121) / 3]$ shows the number of repeated CAG.

Chronic back pain, persistent and annoying in its nature is a frequent MJD patients complaint, possibly due to central changes, particularly in the dopaminergic circuits tract and striatum of the diencephalon, the

${ }^{1}$ Digestive Surgery Division, Hospital das Clínicas da Faculdade de Medicina da Universidade de São Paulo, São Paulo, SP, Brazil; ${ }^{2}$ Laboratory of Research and Evaluation in Physical Activity, Catholic University, Porto Alegre, RS, Brazil.

Correspondence: Prof. Valter Nilton Felix - Al. Ministro Rocha Azevedo, 38 - un. 603 - 01410-00 - São Paulo, SP., Brasil E-mail: v.felix@terra.com.br 
processing of sensory impulses leading to the poor posture, dystonia and peripheral neuropathy ${ }^{(23)}$.

In classic literature dealing with this clinical disease, patients with MJD are considered normal in terms of their mental state ${ }^{(24)}$. However, Ishikawa et al. ${ }^{(8)}$ reported dementia and delirium in four patients with MJD who presented excitation, uncooperative attitude, crying, disorientation, a slow thought process, hallucinations, in which the sequence of CAGs repeated in the MJD chromosome were much longer than the average found in patients with the disease. The electroencephalography of these patients showed reduced brain activity, and computed tomography as well as magnetic resonance imaging of the skull ruled out cortical atrophy.

Poor posture, dystonia and peripheral neuropathy are extremely predisposing to oropharyngeal dysphagia, which is more commonly associated with muscular dystrophy. Thus, with the exception of those rare cases of cognitive impairment, patients with MJD, fully aware of what is happening to them, with evidence of dysphagia, have significant additional commitment to their quality of life.

Food, which not only supports the maintenance of life, is listed as one of the greatest pleasures which can be experienced by man, and this makes it possible to understand the problem that dysphagia causes for patients and their families ${ }^{(4)}$.

However, this problem is not commonly found in current literature, with works that only scratch the surface of deglutition of patients ${ }^{(17,18)}$, or only describe cases ${ }^{(14,22)}$, with conflicting data, motivating the creation of this, a prospective randomized survey, which aims to clinically categorise the dysphagia of patients with MJD, seeking to improve the interdisciplinary therapeutic approach.

\section{METHODS}

Twenty patients with MJD, previously diagnosed by the Neurology Department and confirmed by molecular testing, with moderate ataxia gait, external ophthalmoplegia, postural changes, presenting sporadic fasciculations of face and tongue, and intermittent low back pain, fit the clinical type 1 of the disease ${ }^{(21)}$, all of normal weight, but with clinical complaints of dysphagia since the onset of neurological manifestation, and 20 controls, individuals who did not report any complaints regarding the health and particularly of deglutition, were included.

The survey was conducted in the University of São Paulo Medical School, Department of Gastroenterology, São Paulo, SP, Brazil, and in the Laboratory of Research and Evaluation in Physical Activity, Catholic University of Rio Grande do Sul, Porto Alegre, RS, Brazil.

The patients had no other diseases, nor received any medication routinely, with the exception of analgesics.

The study was approved by the Scientific-Ethical Committees of both institutions and all participants signed informed consent forms.

The patients and the controls, of both sexes over 18 years of age with preserved cognitive responses, having been approved in the mini-exam of mental capacity ${ }^{(3)}$, had attended at least until the fourth grade of elementary school and had not previously undergone any deglutition rehabilitation programme.

Twenty patients with MJD, complaining of high dysphagia, and 20 controls equated in terms of gender distribution and average age (Table 1). The MJD patients were submitted to anamnesis and all the participants in the survey, both patients and controls, underwent clinical evaluation of their deglutition.

TABLE 1. Material

\begin{tabular}{lcc}
\hline & & \\
\hline MJD Patients & 7 men/13 women & $44.75 \pm 10.37$ \\
Controls & 8 men/12 women & $38.55 \pm 11.36$ \\
\hline
\end{tabular}

\section{Anamnesis}

The anamnesis consisted of questioning concerning the time since the MJD diagnosis and the appearance of dysphagia, the presence or absence of coughing or choking during or after meals, the feeling of food stuck in the throat.

Average meal times were also investigated as so as if there had been weight loss or bronchial aspiration after the onset of dysphagia, which food textures proved easier or more difficult to swallow, if the eating itself was pleasurable and if patients fed by themselves, totally independently or with the help of others.

\section{Clinical evaluation of deglutition}

A clinical evaluation was carried out on all subjects, using latex gloves, flashlight, plastic spatula, Littman stethoscope ${ }^{\circledR}$ and portions of $10 \mathrm{~mL}$ of foods: liquid (water/ juice), paste (yogurt) and solid (biscuit).

By means of visual observation, the ability of lip sealing and bilateral lateralization, protrusion and retraction of the tongue were all observed. The tongue tonus was assessed by a motor test, which asked the patient to externalize the tongue as much as possible and resist the force from the spatula. Using spatula, the sensitivity of the forehead, cheeks, chin, and of tip, body, bottom and side portions of the tongue (which was left in the intra-oral resting position) and the gag, cough, palatal and bite reflexes were all tested.

Cervical auscultation was adopted for the clinical evaluation of the pharyngeal phase of deglutition. The stethoscope was positioned on the left side of the neck, the region corresponding to the laryngotracheal junction, anterior to the carotid artery, in order to hear the effectiveness or not of the mechanism for airway protection and if the transit of the bolus was normal or not.

Pharyngeal stasis was identified when there was increased duration of deglutition apnea and multiple gulps at cervical auscultation.

Besides this, the presence or absence of cough and/or choking during the intake of each element swallowed was observed. The issue of high-pitched sounds was asked to evaluate if there was preserved ability of laryngeal elevation.

At the end, the profile of dysphagia in patients with Machado-Joseph disease was classified according to the Severity Scale of Dysphagia, as described by O'Neil et al. ${ }^{(15)}$. 


\section{Statistical analysis}

Data was analyzed using the $\mathrm{c}^{2}$ test, adopting a significance level of $5 \%$.

\section{RESULTS}

In the anamnesis, the MJD patients showed high frequency of coughing or choking during the meal and feeling of food stuck in the throat and it could be observed that the food with the paste texture was easier to swallow and is the preference of all dysphagic patients (Table 2).

TABLE 2. Anamnesis of the MJD patients

\begin{tabular}{lc}
\hline Average disease and dysphagia time & 7 years (range 1-15) \\
\hline Coughing or choking during meals & $19 / 20$ patients \\
Coughing or choking after meals & $6 / 20$ patients \\
Feeling of food stuck in the throat & $17 / 20$ patients \\
Average meal time & 26.5 minutes (range 20-40) \\
Weight loss & $6 / 20$ patients \\
Bronchial aspiration & Absent \\
Paste food texture easier to swallow & $20 / 20$ patients \\
Liquid food texture more difficult to swallow & $9 / 20$ patients \\
Solid food texture more difficult to swallow & $11 / 20$ patients \\
Pleasure of eating & $16 / 20$ patients \\
Independence in feeding habits & $17 / 20$ patients \\
\hline
\end{tabular}

Weight loss was no more than 3 kilograms, most of the sufferers were able to maintain independence in feeding habits and indeed got pleasure from it, but all of them stressed the additional effort and excessive time taken to ingest meals since the beginning of the neurological condition.

With reference to the clinical evaluation of the oral phase of deglutition, comparison with the controls showed significant differences only in regards to less protrusion and retraction ability and higher tonus of the tongue of the patients (Table 3 ).

TABLE 3. Clinical evaluation of the oral phase of deglutition in MJD patients and controls

\begin{tabular}{lccc}
\hline & $\begin{array}{c}\text { Controls } \\
\text { with } \\
\text { dysfunction }\end{array}$ & $\begin{array}{c}\text { MJD patients } \\
\text { with } \\
\text { dysfunction }\end{array}$ & $P$ \\
\hline Lip sealing & 0 & 0 & 1.0000 \\
Tongue right lateralization & 0 & 2 & 0.0734 \\
Tongue left lateralization & 0 & 2 & 0.0734 \\
Tongue protrusion & 0 & 5 & $0.0084^{*}$ \\
Tongue retraction & 0 & 5 & $0.0084^{*}$ \\
Tongue tonus & 0 & 14 & $0.00001^{*}$ \\
Sensitivity of the forehead & 0 & 0 & 1.0000 \\
Sensitivity of the cheeks & 0 & 0 & 1.0000 \\
Sensitivity of the chin & 0 & 0 & 1.0000 \\
Sensitivity of side portions of the tongue & 0 & 0 & 1.0000 \\
Sensitivity of the tip of the tongue & 0 & 0 & 1.0000 \\
Sensitivity of the body of the tongue & 0 & 0 & 1.0000 \\
Sensitivity of the bottom of the tongue & 0 & 0 & 1.0000 \\
Gag reflex & 0 & 0 & 1.0000 \\
Cough reflex & 0 & 0 & 1.0000 \\
Palatal reflex & 0 & 0 & 1.0000 \\
Bite reflex & 0 & 0 & 1.0000 \\
\hline
\end{tabular}

* statistically significant differences
However, with regards to the pharyngeal phase, there were several significant differences noted, with dysphagic patients presenting pharyngeal stasis at the deglutition of liquids and solids, often accompanied by coughing and/or choking and penetration or aspiration (Table 4).

In the same table it is observed that all subjects showed, at the issue of high-pitched sounds, preserved ability of laryngeal elevation, and the deglutition of paste not resulting in pharyngeal stasis, coughing, choking, signals of penetration or aspiration of food.

Considering the data coming from the history of patients and the variables of clinical evaluation where statistically significant differences in the ratio patients/controls could be seen, the profile of the dysphagia of patients with MJD was compatible with the level 4 (mild/moderate dysphagia) on the O'Neil et al. ${ }^{(15)}$ Severity Scale of Dysphagia.

\section{DISCUSSION}

Patients with oropharyngeal dysphagia commonly present muscle dysfunction in the lips, tongue, palate, and/or pharynx, as well as incoordination of deglutition movements ${ }^{(7)}$.

The controls did not show any changes whatsoever to the clinical evaluation of deglutition, in both the oral phase and that of the pharyngeal, but as was expected, according to the classic features of $\mathrm{MJD}$, the dysphagic patients demonstrated deficiencies in the oral phase of deglutition, related to the protrusion, retraction and tonus of the tongue, which, however, had adequate sensitivity and lateral mobility, with the lips closing and reflexes maintained throughout the various tests performed.

As for the analysis of the pharyngeal phase, cervical auscultation is a tool that enables the hearing of the distinctive sounds of deglutition, with the use of a stethoscope. The sounds resulting from the movement of food towards the airway are different from those of a normal deglutition ${ }^{(2)}$.

Cervical auscultation is inexpensive, noninvasive and easy to use ${ }^{(10)}$. Cervical sounds of adult and infant swallowing have been qualitatively described ${ }^{(1,19)}$. It is a method of listening to the sounds of swallowing during the pharyngeal phase to detect patients with dysphagia. Typically, a stethoscope is placed at the lateral aspects above the cricoids cartilage in front of the sternocleidomastoid muscle and the large vessels.

When clinicians listen to the swallowing sounds with a stethoscope, qualitative judgments are made about what is heard. Based on the sharpness of the sound, the characteristic swishing double-click as the bolus passes through the pharynx and into the esophagus is judged for normalcy. However, all recordings from dysphagic patients show multiple gulps ${ }^{(6)}$.

Zenner et al. ${ }^{(25)}$ support the use of clinical evaluation with cervical auscultation as a highly sensitive and specific method of dysphagia assessment in long-term care. A clinical examination using auscultation could successfully distinguish between subjects who aspirate and those who do not. Moreover, the results of his study support the clinical examination as a tool for determining appropriate dietetic treatment in longterm care when cervical auscultation is used. 
TABLE 4. Clinical evaluation of the pharyngeal phase of deglutition in MJD patients and controls

\begin{tabular}{|c|c|c|c|c|c|}
\hline & \multicolumn{2}{|c|}{ Controls } & \multicolumn{2}{|c|}{ MJD patients } & \multirow{2}{*}{$P$} \\
\hline & No & Yes & No & Yes & \\
\hline Preserved ability of laryngeal elevation & 0 & 20 & 0 & 20 & 1.0000 \\
\hline Penetration and/or aspiration of liquids & 20 & 0 & 10 & 10 & $0.0001 *$ \\
\hline Coughing and/or choking at the deglutition of liquids & 20 & 0 & 10 & 10 & $0.0001^{*}$ \\
\hline Pharyngeal stasis of liquids & 20 & 0 & 15 & 5 & $0.0084 *$ \\
\hline Penetration and/or aspiration of paste food & 20 & 0 & 20 & 0 & 1.0000 \\
\hline Coughing and/or choking at the deglutition of paste food & 20 & 0 & 20 & 0 & 1.0000 \\
\hline Pharyngeal stasis of paste food & 20 & 0 & 20 & 0 & 1.0000 \\
\hline Penetration and/or aspiration of solid food & 20 & 0 & 5 & 15 & $0.00001 *$ \\
\hline Coughing and/or choking at the deglutition of solid food & 20 & 0 & 10 & 10 & $0.0001 *$ \\
\hline Pharyngeal stasis of solid food & 20 & 0 & 2 & 18 & $0.00001 *$ \\
\hline
\end{tabular}

* statistically significant differences

Actually continued efforts have been done in this field focus on providing objective, measurable, and reproducible techniques to increase the acceptance and utility of the cervical auscultation in research and clinical applications ${ }^{(2)}$.

It can be noted then that the dysphagic patients showed more marked dysfunction, backed up by statistics, in relation to the controls, in the deglutition of liquids and solids, with pharyngeal stasis, with cough and/or choking and penetration or aspiration, typical of a moderate dysphagia ${ }^{(5)}$, changes absent in controls, although the larynx elevated effectively, thus reflecting a lack of coordination of movements of the structures involved in the process.

It was clear at the end of the clinical evaluation, why the pastes, as mentioned in anamnesis, were preferred by patients, since they did not promote pharyngeal stasis, the appearance of choking or coughing or signals of penetration or aspiration if swallowed.

The Severity Scale of Dysphagia described by O'Neil et al. ${ }^{(15)}$, which ranks dysphagia from 7 (deglutition normal) to 1 (severe dysphagia), considers that the restriction to two or more food consistences, and penetration and/or aspiration supported by effective cough, should be ranked at level 4 (mild/ moderate dysphagia), and it is this which fits the profile of dysphagia of patients with MJD of clinical type 1, obtained in this study, when considering the data coming from the history of patients and the variables of clinical evaluation in which statistically significant differences in the ratio patients/ controls were achieved.

This justifies that these patients are addressed in an interdisciplinary way, with the inclusion of the rehabilitation program of deglutition in treatment planning, including in order to prevent serious respiratory complications, which they are potentially subject to.

\section{CONCLUSIONS}

A survey conducted with 20 patients suffering from MJD of clinical type 1, submitted to anamnesis and clinical evaluation of deglutition, controlled by 20 individuals without any medical complaints, concluded that:

1.Oropharyngeal dysphagia is part of the disease since the first neurological manifestations;

2.There is greater involvement of the pharyngeal phase, in relation to oral phase of the deglutition;

3.The dysphagia of these patients is classified between mild and moderate.

Corrêa SMA, Felix VN, Gurgel JL, Sallum RAA, Cecconello I. Avaliação clínica da disfagia orofaríngea na doença de Machado-Joseph. Arq Gastroenterol. 2010;47(4):334-8.

RESUMO - Contexto - Na doença de Machado-Joseph, a má postura, a distonia e a neuropatia periférica predispõem à disfagia orofaríngea, mais comumente associada à distrofia muscular. Objetivo - Avaliar as características clínicas da disfagia orofaríngea em pacientes com doença de Machado-Joseph. Métodos - Quarenta indivíduos participaram do estudo, incluindo 20 sem quaisquer queixas clínicas e 20 disfágicos com doença de Machado-Joseph do tipo clínico 1, grupos similares em termos de sexo, média de idade e função cognitiva. Foi verificada a história clínica de cada paciente e todos os indivíduos passaram por avaliação clínica da deglutição. Ao final, a disfagia dos enfermos com doença de Machado-Joseph foi classificada de acordo com a Escala de Severidade da Disfagia. Resultados - A comparação entre disfágicos e controles não revelou muitas diferenças significativas quanto à avaliação clínica da fase oral da deglutição, visto que os pacientes demonstraram déficits apenas relacionados à protrusão, retração e tônus linguais. Entretanto, em relação à fase faríngea, várias alterações relevantes, ausentes nos controles, foram notadas nos pacientes, tais como estase faríngea à deglutição de líquidos e sólidos, acompanhada de tosse e/ou engasgo, assim como de penetração e/ou aspiração laringotraqueal. Conclusões - Disfagia orofaríngea faz parte da doença de Machado-Joseph desde as primeiras manifestações neurológicas. Há maior comprometimento da fase faríngea, em relação à fase oral da deglutição. A disfagia desses pacientes é classificada entre leve e moderada.

DESCRITORES - Doença de Machado-Joseph. Transtornos de deglutição. 


\section{REFERENCES}

1. Burke PM. Swallowing and the organization of sucking in the human newborn Child Dev. 1977;48:523-31.

2. Cichero JA, Murdoch BE. Detection of deglutition sound: methodology revisited. Dysphagia. 2002;17:40-9.

3. Erné AS. O exame do estado mental do paciente. In: Cunha JA, editor Psicodiagnóstico. 5a ed. Porto Alegre: Artmed; 2003. p.67-74.

4. Felix VN, Fúria CLB, Freitas GC, Mansur LL, Sugueno LA, Mendonça LI Z, Corrêa LS, Durazzo M, Pucci ND, Danilewsky VC. Disfagia orofaríngea e implicações nutricionais. In: Waitzberg DL, editor. Nutrição oral, enteral e parenteral da prática clínica. $4^{a}$ ed. São Paulo: Atheneu; 2009. v.2, p.2007-36.

5. Furkim AM, Silva RG. Programas de reabilitação em disfagias neurogênicas. São Paulo: Frôntis; 1999.

6. Hamlet S, Penney DG, Formolo J. Stethoscope acoustics and cervical auscultation of swallowing. Dysphagia. 1994;9:63-8.

7. Huckabee ML, Cannito MP. Outcomes of deglutition rehabilitation in chronic brainstem dysphagia: a retrospective evaluation. Dysphagia. 1999;12:93-109.

8. Ishikawa A, Yamada M, Makino K, Aida I, Idezuka J, Ikeuchi T, Soma Y, Takahashi H, Tsuji S. Dementia and delirium in 4 patients with Machado-Joseph disease. Arch Neurol. 2002;59:1804-8

9. Kawaguchi Y, Okamoto T, Taniwaki M, Aizawa M, Inoue M, Katayama S, Kawakami H, Nakamura S, Nishimura M, Akiguchi I, Kimura J, Narumya S, Kakizuka A. CAG expansions in a novel gene for Machado-Joseph disease at chromosome 14q32. Nat Genet. 1994;8:221-8.

10. Lefton-Greif MA, Loughlin GM. Specialized studies in pediatric dysphagia. Semin Speech Lang. 1996;17:311-29.

11. Lopes-Cendes I, Maciel P, Kish S, Gaspar C, Robitaille Y, Clark HB, Koeppen AH, Nance M, Schut L, Silveira I, Coutinho P, Sequeiros J, Rouleau GA. Somatic mosaicism in the central nervous system in spinocerebellar ataxia type 1 and Machado-Joseph disease. Ann Neurol. 1996;40:199-206.

12. Martins S, Calafell F, Gaspar C, Wong VC, Nicholson GA, Brunt ER, Tranebjaera L, Stevanin G, Hsieh M, Soong BW, Loureiro L, Dürr A, Tsuji S, Watanabe M, Jardim LB, Giunti P, Riess O, Ranum LP, Brice A, Rouleau GA, Coutinho P, Amorim A, Sequeiros J. Asian origin for the worldwide-spread mutational event in Machado-Joseph disease. Arch Neurol. 2007;64:1502-8.

13. Nakano KK, Dawson DM, Spence A. Machado-Joseph disease: a hereditary ataxia in Portuguese emigrants to Massachusetts. Neurology. 1972;22:49-55.

14. Nisa-e-Castro SAF, Paniagua LM, Santos AC. Efeito do envelhecimento nas manifestações fonoaudiológicas da doença de Machado-Joseph - relato de um caso. Estud Interdisc Envelhec. 2005;8:99-113.

15. O'Neil KH, Purdy M, Falk J, Gallo L. The dysphagia outcome and severity scale. Dysphagia. 1999;14:139-45.

16. Radvany J, Ávila JO, Gabbai AA, Bacheschi LA. Doença de Machado Joseph: as duas primeiras famílias relatadas no Brasil. Arq Neuropsiquiatr. 1988;46(Suppl):152.

17. Ramio-Torrentia L, Gomez E, Genis D. Swallowing in degenerative ataxias. J Neurol. 2006;253:875-81

18. Rüb U, Brunt ER, Del Turco D, De Vos RA, Gierga K, Paulson H, Braak H. Guidelines for the pathoanatomical examination of the lower brainstem in ingestive and deglutition disorders and its application to a dysphagic spinocerebellar ataxia type 3 patient. Neuropathol Appl Neurobiol. 2003;29:1-13.

19. Soentgen ML, Pierce L, Brenman HS. Mouthing activities in the human neonatal sucking act. Arch Oral Biol. 1969;14:1159-67.

20. Takiyama Y, Nishizawa M, Tanaka H, Kawashima S, Sakamoto H, Karube Y, Shimazaki H, Soutome M, Endo K, Ohta S, Kagawa Y, Kanazawa I, Mizuno Y, Yoshida M, Yuasa T, Horikawa Y, Oyanagi K, Nagai H, Kondo T, Inuzuka T, Onodera O, Tsuji S. The gene for Machado-Joseph disease maps to human chromosome 14q. Nat Genet. 1993;4:300-4

21. Teive HAG. Ataxias. In: Lopes AC, Vicente AN, editores. Tratado de clínica médica. São Paulo: Roca; 2006. v.2, p.2270-88.

22. Wolf A, Mourão L, Beilke H, França Jr M, Silva A, Lopes Cendes I, Crespo A Deglutition in Machado Joseph's disease: preliminary study of 7 cases [abstract] In: Fifteenth Annual Dysphagia Research Society Meeting, 2007, Scientific Poster Sessions, Vancouver BC, Canadá. Dysphagia. 2007;22:372.

23. Yamamoto M, Kachi T, Sobue G. Pain-related and electrically stimulated somatosensory evoked potentials in patients with Machado-Joseph disease and multiple system atrophy. Intern Med. 1997;36:550-5.

24. Zawacki TM, Grace J, Friedman JH, Sudarsky L. Executive and emotional dysfunction in Machado-Joseph disease. Mov Disord. 2002;17:1004-10.

25. Zenner PM, Losinski DS, Mills RH. Using cervical auscultation in the clinical dysphagia examination in long-term care. Dysphagia. 1995;10:27-31.

26. Zhou YX, Takiyama Y, Igarashi S, Li YF, Zhou BY, Gui DC, Endo K, Tanaka H, Chen ZH, Zhou LS, Fan MZ, Yang BX, Weissenbach J, Wang GX, Tsuji S Machado-Joseph disease in four Chinese pedigrees: molecular analysis of 15 patients including two juvenile cases and clinical correlations. Neurology. 1997;48:482-5.

Received 22/10/2009

Accepted 22/1/2010 